\title{
Hypoglucemic Effect Exerted by an Ethynyl- Phenylamino-Steroid-Pyrazole Derivative against Glucose Levels using a Diabetic Model
}

López-Ramos Maria ${ }^{1}$ (D) , Figueroa-Valverde Lauro ${ }^{1, *}$ (D), Alvarez-Ramirez Magdalena 2,* (D), Díaz-Cedillo Francisco $^{3}$ (D), Rosas-Nexticapa Marcela ${ }^{2}$ (D), Mateu-Armad Maria Virginia 2(D), Cervantes-Ortega Catalina $^{2(D)}$, Arakachi-Cruz Idalia 4 (D), Salgado-Alarcon Kelly 4 (D), Estrella-Barron Raquel 5 (D), CauichCarrillo Regina 1 (D)

1 Laboratory of Pharmaco-Chemistry, Faculty of Chemical Biological Sciences, University Autonomous of Campeche, Av. Agustín Melgar s/n, Col Buenavista C.P. 24039 Campeche, Camp., México

2 Nutrition Faculty, Veracruzana University, Médicos y Odontologos s/n C.P. 91010, Unidad del Bosque Xalapa Veracruz, México

3 National School of Biological Sciences of the National Polytechnic Institute. Prol. Carpio y Plan de Ayala s/n Col. Santo Tomas, D.F. C.P. 11340, México

4 Modelo University, Campus Chetumal, Carretera Federal Chetumal-Subteniente Lopez s/n, Quintana Roo, Mexico

5 Autonomous University of Carmen, Faculty of Health Sciences, Campus III, Av. Central s/n Esq. Fracc. Mundo Maya, C.P. 24153 Ciudad del Carmen, Campeche, Mexico

* Correspondence: Ifiguero@uacam.mx (F.V.L); malvarez@uv.mx (A.R.M);

Received: 19.02.2021; Revised: 15.04.2021; Accepted: 20.04.2021; Published: 9.05.2021

Abstract: The research aimed to prepare an ethynyl-phenylamino-steroid-pyrazole derivative to evaluate their hypoglycemic activity in a diabetic model using either metformin or glibenclamide as controls. Besides, a theoretical analysis was carried out to evaluate estrone derivative interaction with either insulin receptor (3iga) or potassium channel ( 3 w 12$)$. The results showed that steroid derivatives decrease glucose levels, and this effect was in a similar form to metformin. Besides, other data suggest that the ethynyl-phenylamino-steroid-pyrazole derivative could have a higher interaction with the 3iga protein surface compared with metformin. In conclusion, the hypoglycemic activity exerted by the ethynyl-phenylamino-steroid-pyrazole derivative against glucose levels is interesting. In this way, this compound could be a good candidate for the treatment of diabetes.

Keywords: estrone; glucose; glibenclamide; metformin.

(c) 2021 by the authors. This article is an open-access article distributed under the terms and conditions of the Creative Commons Attribution (CC BY) license (https://creativecommons.org/licenses/by/4.0/).

\section{Introduction}

Diabetes is a risk factor for developing cardiovascular diseases worldwide [1-3]. Some drugs such as glibenclamide [4], metformin [5], acarbose [6], rosiglitazone [7] have been used for the treatment of this clinical pathology. However, it has been observed that some of these drugs can cause adverse effects, such as [8,9], arrhythmia [10], lactic acidosis [11], myocardial infarction [12], and others. In the search for new drugs for the treatment of diabetes, some compounds have been prepared. In this way, an indole derivative was synthesized from tetrafluoroaniline and pyridine as a hypoglycemic agent. [13]. Furthermore, another study showed the synthesis of 2-amino-5-chloro benzothiazole from 4-chloro aniline and hypoglycemic activity against diabetes. [14]. Additionally, a report showed the synthesis of a 
pyran-3,4,5-triol derivative from xylose as a sodium-dependent glucose cotransporter 2 inhibitor for treating Type 2 Diabetes [15]. Other reports showed the synthesis of a butanamide derivative from 2-Methyl-5-bromobenzoic acid as sodium-dependent glucose cotransporter 1 Inhibitor in a diabetic model [16].

On the other hand, some reports indicate that steroids exert biological activity against diabetes; for example, a report showed that either 2-methoxyestradiol or 2-ethoxyestradiol can decrease the levels of glucose in an animal diabetic model [17]. Besides, a study showed the synthesis of a progesterone-dihydropyrimidine derivative from progesterone with hypoglycemic activity [18]. All these data suggest that some steroid-derivatives exert effects on glucose levels; However, there are very few studies on the biological activity produced by estrone derivatives on glucose levels; in this way, this investigation aimed to synthesize an estrone derivative (Ethynyl-phenylamino-steroid-pyrazole) to evaluate their hypoglycemic activity using a diabetic model.

\section{Materials and Methods}

\subsection{General.}

The compound 1 (17-chloro-16-formyl- $\Delta 1,3,5(10), 16$-estratetraenol) was prepared using a previously method reported [19]. Besides, the reagents used in this research were acquired from Sigma-Aldrich Co., Ltd. The melting point (m.p.) for compounds was determined using an Electrothermal (900 model). Infrared spectra (IR) were determinate on a Thermo Scientific iSOFT-IR spectrometer. ${ }^{1} \mathrm{H}$ and ${ }^{13} \mathrm{C}$ NMR spectra were evaluated using a Varian VXR300/5 FT NMR spectrometer at $300 \mathrm{MHz}$ in deuterated chloroform using Tetramethylsilane as an internal standard. Electron ionization-Mass Spectra ( EIMS) was determinate with a Finnigan Trace Gas Chromatography Polaris Q-Spectrometer. Elementary analysis data was registered using a Perkin Elmer Ser. II CHNS/02400 apparatus.

\subsubsection{Synthesis.}

\section{7-Chloro-13-methyl-16-(phenyl-hydrazonomethyl)-7,8,9,11,12,13,14,15,16,17-}

decahydro-6H-cyclopenta[a]phenanthren-3-ol (2). In a round bottom flask $(10 \mathrm{ml})$, compound 1 (200 mg, $0.63 \mathrm{mmol}$ ), phenylhydrazine ( $70 \mathrm{mg}, 0.64$ ), boric acid (40 mg, 0.64 $\mathrm{mmol}$ ) and methanol $(5 \mathrm{ml})$ were stirred to room temperature for $72 \mathrm{~h}$. After, the solvent was evaporated under reduced pressure. The product was purified using the methanol: hexane: water system (3: 1: 1); giving a yield of $45 \%$; m.p. 124-126 ${ }^{\circ} \mathrm{C}$; IR $\left(V_{\max }, \mathrm{cm}^{-1}\right) 3400,3326$ and 3310: ${ }^{1} \mathrm{H}$ NMR (300 MHz, $\left.\mathrm{CDCl}_{3}-d\right) \delta_{\mathrm{H}}$ : 1.02, 1.16-4.60 (m, 15H), 6.54 (broad, 2H), 6.60-6.66 $(\mathrm{m}, 2 \mathrm{H}), 7.00-7.05(\mathrm{~m}, 5 \mathrm{H}), 7.26(\mathrm{~m}, 1 \mathrm{H}), 8.14(\mathrm{~m}, 1 \mathrm{H}) \mathrm{ppm} .{ }^{13} \mathrm{C} \mathrm{NMR}\left(300 \mathrm{~Hz}, \mathrm{CDCl}_{3}\right) \delta_{\mathrm{C}}$ : 15.12 , 26.60, 27.46, 31.00, 31.06, 36.74, 37.76, 43.88, 45.42, 49.32, 50.80, 72.34, 113.22, 115.26, 115.56, 121.12, 128.70, 128.44, 133.96, 138.22, 146.30, 149.12, 155.00 ppm. EI-MS m/z: 408.19. Anal. Calcd. for $\mathrm{C}_{25} \mathrm{H}_{29} \mathrm{ClN}_{2} \mathrm{O}: \mathrm{C}, 73.42 ; \mathrm{H}, 7.15 ; \mathrm{Cl}, 8.67 ; \mathrm{N}, 6.85 ; \mathrm{O}, 3.91$. Found: C, 73.40; H, 7.12.

6a-Methyl-7-phenyl-4b,5,6,6a,6b,7,9a,10,10a,10b,11,12-dodecahydro-7,8-diazapentaleno[2,1-a]phenanthren-2-ol (3). In a round bottom flask $(10 \mathrm{ml})$, compound $2(200 \mathrm{mg}$, $0.49 \mathrm{mmol})$, Copper(II) chloride $(67 \mathrm{mg}, 0.5)$ and methanol $(5 \mathrm{ml})$ were stirred to room temperature for $72 \mathrm{~h}$. After, the solvent was evaporated under reduced pressure. The product was purified using the methanol:hexane:water (3:1:1) system; giving a yield of 52\%; m.p. 118$120{ }^{\circ} \mathrm{C}$; IR $\left(V_{\max }, \mathrm{cm}^{-1}\right) 3400,3328$ and $1182:{ }^{1} \mathrm{H}$ NMR $\left(300 \mathrm{MHz}, \mathrm{CDCl}_{3}-d\right) \delta_{\mathrm{H}}: 0.80,1.06-$ 
$1.90(\mathrm{~m}, 7 \mathrm{H}), 2.00-2.80(\mathrm{~m}, 6 \mathrm{H}), 3.40-3.62(\mathrm{~m}, 2 \mathrm{H}), 5.56$ (broad, 1H), $6.44(\mathrm{~m}, 1 \mathrm{H}), 6.60-6.66$ $(\mathrm{m}, 2 \mathrm{H}), 6.86-7.06(\mathrm{~m}, 5 \mathrm{H}), 7.12(\mathrm{~m}, 1 \mathrm{H}) \mathrm{ppm} .{ }^{13} \mathrm{C} \mathrm{NMR}\left(300 \mathrm{~Hz}, \mathrm{CDCl}_{3}\right) \delta_{\mathrm{c}}: 15.00,27.46$, 27.70, 29.80, 31.00, 37.02, 38.90, 40.30, 48.60, 49.26, 53.76, 76.08, 112.26, 113.22, 115.60, 120.12, 127.22, 128.66, 132.13, 138.68, 140.90, 155.00, 157.70 ppm. EI-MS m/z: 372.22. Anal. Calcd. for $\mathrm{C}_{25} \mathrm{H}_{28} \mathrm{~N}_{2} \mathrm{O}$ : C, 80.61; H, 7.58; N, 7.52; O, 4.30. Found: C, 80.58; H, 7.55.

1-[(3-Ethynyl-phenylamino)-methyl]-6a-methyl-7-phenyl-4b,5,6,6a,6b,7, 9a,10,10a,10b, 11, 12-dodecahydro-7,8-diaza-pentaleno[2,1-a]phenanthren-2-ol (4). In a round bottom flask $(10 \mathrm{ml})$, compound $3(200 \mathrm{mg}, 0.53 \mathrm{mmol}), 3$-ethynylaniline $(60 \mathrm{mg}, 0.55$ mmol), and formaldehyde $(5 \mathrm{ml})$ were stirred to reflux for $12 \mathrm{~h}$. After, the solvent was evaporated under reduced pressure. The product was purified using the methanol:hexane: (3:1) system; giving a yield of 56\%; m.p. 56-58 ${ }^{\circ} \mathrm{C}$; IR $\left(V_{\max }, \mathrm{cm}^{-1}\right) 3400,3326,3310,2138$ and 1180: ${ }^{1} \mathrm{H}$ NMR $\left(300 \mathrm{MHz}, \mathrm{CDCl}_{3}-d\right) \delta_{\mathrm{H}}: 0.80,1.06-1.90(\mathrm{~m}, 7 \mathrm{H}), 2.00-2.52(\mathrm{~m}, 6 \mathrm{H}), 2.88(\mathrm{~s}$, 1H), 3.40-3.62 (m, 2H), 4.22 (m, 2H), 5.66 (broad, 2H), 6.44 (m, 1H), 6.60-6.66 (m, 2H), 6.68$6.74(\mathrm{~m}, 2 \mathrm{H}), 6.86-7.06(\mathrm{~m}, 5 \mathrm{H}), 7.12-7.14(\mathrm{~m}, 2 \mathrm{H}) \mathrm{ppm} .{ }^{13} \mathrm{C} \mathrm{NMR}\left(300 \mathrm{~Hz}, \mathrm{CDCl}_{3}\right) \delta \mathrm{c}: 15.00$, 27.40, 27.46, 28.00, 29.00, 37.02, 38.10, 38.90, 40.30, 47.72, 49.26, 52.74, 76.08, 78.22, 84.00, $112.26,112.56,113.12,120.12,122.50,122.72,123.50,125.00,128.22,128.68,129.85$, 131.66, 138.60, 140.90, 149.70, 150.10, 157.70 ppm. EI-MS m/z: 501.27. Anal. Calcd. for $\mathrm{C}_{34} \mathrm{H}_{35} \mathrm{~N}_{3} \mathrm{O}: \mathrm{C}, 81.40 ; \mathrm{H}, 7.03 ; \mathrm{N}, 8.38$; O, 3.19. Found: C, 81.36; H, 7.00.

\subsection{Biological activity.}

\subsubsection{General methods.}

Experimental methods used were reviewed and approved by the Animal Care and Use Committee of Autonomous University of Campeche and were in accordance with the Guide for the Care and Use of Laboratory Animals [20]. Male rats (Wistar, weighing 200-250 g) were obtained from the Autonomous University of Campeche (Pharmacochemistry laboratory).

\subsubsection{Induction of diabetes.}

Alloxan $(150 \mathrm{mg} / \mathrm{kg})$ was administered to animals intraperitoneally using a previously reported report [21].

\subsubsection{Glucose analysis.}

To determine glucose levels, the qualitative test of Benedict's [22] was used. It is important to mention that the blood glucose concentration was registered from the tail blood using a glucose analyzer (Accutrend Sensor Comfort; Roche, USA) every $48 \mathrm{~h}$. The values of hyperglycemia (blood glucose $\geq 200 \mathrm{mg} / \mathrm{dl}$ ) were used for all experiments.

\subsection{Experimental design (I).}

The rats were divided into sixteen groups after the induction of diabetes. Six rats were used in each group (40 diabetic surviving rats, six normal rats).

Group 1: Normal rats were given $2 \mathrm{ml}$ of normal saline.

Group 2: Diabetic control rats were given $2 \mathrm{ml}$ of normal saline.

Group 3 Diabetic rats were given an aqueous solution of glibenclamide ${ }^{\phi}(600 \mu \mathrm{g} / \mathrm{kg}$ body mass) daily with an intragastric tube for 30 days. 
Group 4: Diabetic rats were given an aqueous solution of metformin ${ }^{\varpi}$ (350 mg/kg body mass) daily had an intragastric tube for 30 days.

Group 5: Diabetic rats were given an aqueous solution of compound $4(2.5 \mathrm{mg} / \mathrm{ml})$ daily with an intragastric tube for 30 days.

Group 6: Diabetic rats were given an aqueous solution of compound $4(5 \mathrm{mg} / \mathrm{ml})$ daily with an intragastric tube for 30 days.

Group 7: Diabetic rats were given an aqueous solution of compound $4(15 \mathrm{mg} / \mathrm{ml})$ daily with an intragastric tube for 30 days.

Group 8: Diabetic rats were given an aqueous solution of compound $4(20 \mathrm{mg} / \mathrm{ml})$ daily with an intragastric tube for 30 days.

${ }^{\phi, \varpi}$ Doses administered of either glibenclamide or metformin were determined using a previously reported method [21].

\subsection{Statistical analysis.}

The results were expressed as average \pm standard error. The data were put under an analysis of variance (ANOVA) using the Bonferroni correction factor on the SPSS 12.0 program [23]. The differences between average were considered significant when $\boldsymbol{p}$ was equal or smaller than 0.05 .

\section{Results and Discussion}

Several hypoglycemic drugs have been synthesized; however, several protocols use some reagents which require special conditions [13-18]. In this investigation, an estrone derivative was prepared to evaluate their hypoglycemic activity against glucose levels using a diabetic model. The first stage was achieved as follows:

\subsection{Chemistry.}

\subsubsection{Preparation of an imino derivative.}

Several studies have shown the preparation of imino groups [24, 25]; However, some protocols require special conditions such as differences in either $\mathrm{pH}$ and temperature. In this way, compound 2 was prepared via a reaction of 1 with phenylhydrazine in the presence of boric acid (Figure 1). The ${ }^{1} \mathrm{H}$ NMR spectrum from 2 showed several signals at $1.02 \mathrm{ppm}$ for methyl group; at 1.16-4.60, 656-6.66, and 7.26 ppm for steroid moiety; at 7.00-7.05 ppm for phenyl group; at $8.14 \mathrm{ppm}$ for imino group. ${ }^{13} \mathrm{C}$ NMR spectra showed chemical shifts at 15.12 ppm for methyl group; at 26.60-113.22, 115.56, 128.70, 133.96-138.22, and $15.00 \mathrm{ppm}$ for steroid moiety; at 115.26, 121.12, 128.44 and $149.12 \mathrm{ppm}$ for phenyl group; at $148.30 \mathrm{ppm}$ for imino group. Besides, the mass spectrum from 2 showed a molecular ion (m/z) 408.19.

\subsubsection{Synthesis of a steroid-pyrazole derivative.}

There are some reports which showed the preparation of several a pyrazole derivatives using several reagents such as $\mathrm{N}$-monosubstituted hydrazones/nitroolefins [26], oxaziridine [27], Sylver(I) [28], $\mathrm{Cu}(\mathrm{OAc})_{2}$ [29], [Cp* $\mathrm{RhCl}_{2}$ ]2 [30] and others. In this study, a steroidpyrazole derivative was prepared via an intramolecular reaction of compound 2 in the presence of Copper(II) chloride (Figure 1). The ${ }^{1} \mathrm{H}$ NMR spectrum from 3 showed several signals at 0.80 ppm for methyl group; at 1.06-2.80, 6.60-6.66, and 7.12 ppm for steroid moiety; at 3.40-3.62 and $6.44 \mathrm{ppm}$ for pyrazole ring; at 6.86-7.06 ppm for phenyl group; at $5.56 \mathrm{ppm}$ for a hydroxyl 
group. ${ }^{13} \mathrm{C}$ NMR spectra showed chemical shifts at $15.00 \mathrm{ppm}$ for methyl group; at 27.46 49.26, 113.22-115.60, 127.22, 132.13-138.68 and 15.00 ppm for steroid moiety; at 53.76-76.08 and $157.70 \mathrm{ppm}$ for pyrazole ring; at 112.26, 120.12, 12.66 and $140.90 \mathrm{ppm}$ for phenyl group. In addition, the mass spectrum from 3 showed a molecular ion $(\mathrm{m} / \mathrm{z}) 372.22$.

\subsubsection{Preparation of an Ethynyl-phenylamino-steroid-pyrazole derivative.}

Several amino-steroid derivatives have been prepared using the Mannich reaction [31, 32]; Thus, compound 3 reacted with Ethynilaniline in the presence of formaldehyde to form compound 4 (Figure 1). The ${ }^{1} \mathrm{H}$ NMR spectrum from 4 showed several signals at $0.80 \mathrm{ppm}$ for methyl bound to steroid nucleus; at 1.06-2.52 and 6.68-6.74 ppm for steroid moiety; at 3.403.62 and $6.44 \mathrm{ppm}$ for pyrazole ring; at 4.22 for methylene bound to steroid nucleus; at 5.66 ppm for both amino and hydroxyl groups; at 6.60-6.66 and 7.12-7.14 ppm for phenyl group bound to both amino and alkyne groups; at 6.86-7.02 ppm for phenyl group bound to pyrazole ring. ${ }^{13} \mathrm{C}$ NMR spectra showed chemical shifts at $15.00 \mathrm{ppm}$ for methyl bound to steroids nucleus; at 27.40-38.90, 47.72-49.26, 112.56, 123.50, 128.22, 131.66-138.60, and $150.10 \mathrm{ppm}$ for steroid moiety; at $40.30 \mathrm{ppm}$ for methylene bound to steroid nucleus; at 53.74-76.08 and 157.70 ppm for pyrazole ring; at 78.22-84.00 ppm for alkyne group; at 112.26-120.12, 128.68 and $140.90 \mathrm{ppm}$ for phenyl group bound to pyrazole ring; at 113.12, 122.50-122.72, 125.00 and 129.85-149.70 ppm for phenyl bound to both amino and alkyne groups. Finally, the mass spectrum from 4 showed a molecular ion $(\mathrm{m} / \mathrm{z}) 501.27$.
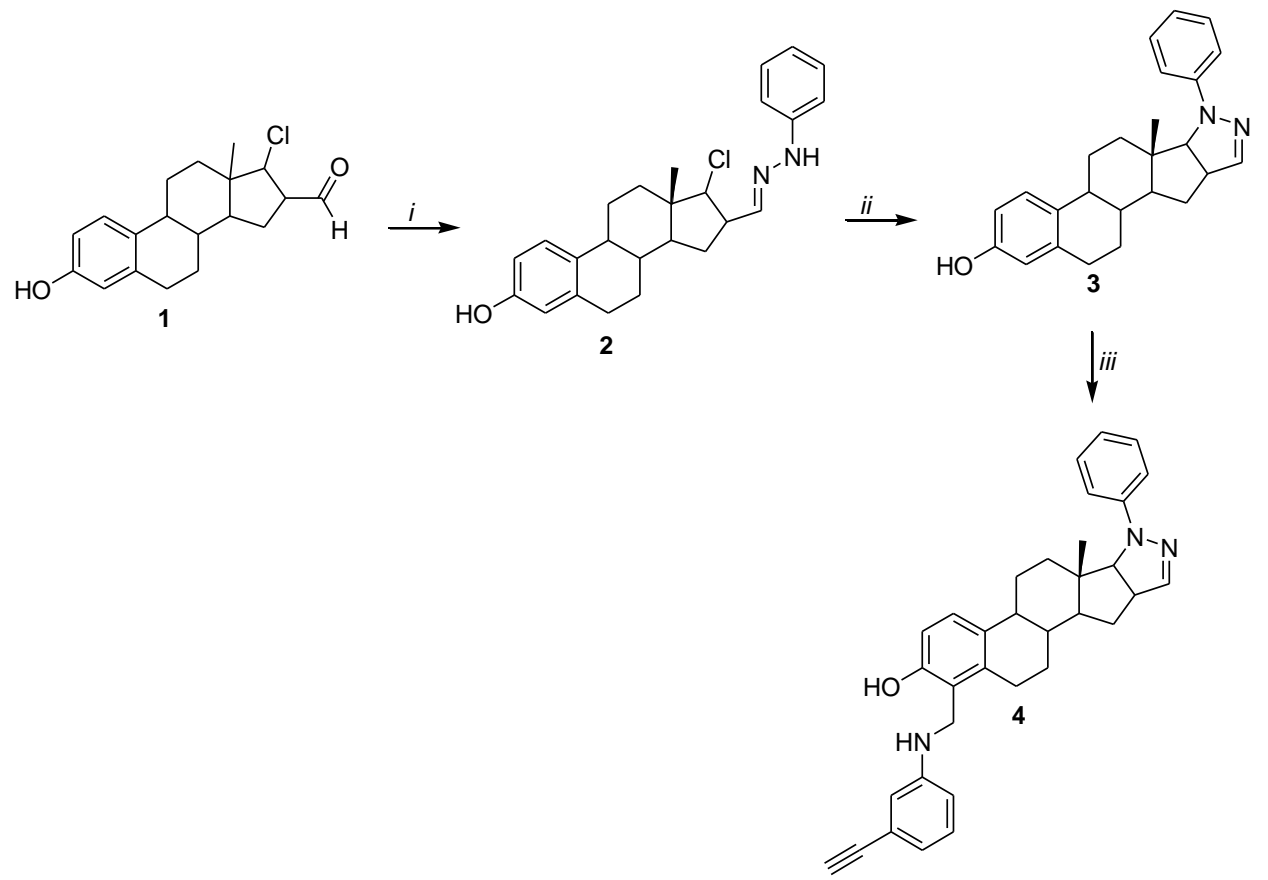

Figure 1. Synthesis of estrone derivatives (4). Reagents and conditions; $i=$ phenylhydrazine, boric acid, methanol room temperature, 72 h.; $i i=$ Copper(II) chloride, room temperature, $72 \mathrm{~h}$; $i i i=3$-ethynylaniline, formaldehyde, reflux, $12 \mathrm{~h}$.

\subsection{Biological activity.}

\subsubsection{Glucose analysis.}

The effect exerted by the compound estrone-derivative against glucose concentration was evaluated using a diabetic animal model. In the first stage, alloxan was administered to male rats to induce diabetes; it is noteworthy that alloxan reagents can produce massive insulin 
release reduction via the destruction of $\beta$-cells of the islets Langerhans, which results in an indirect increase in the glucose levels [33]. Therefore, the biological activity exerted by the estrone derivative on glucose concentration was evaluated. using either metformin (insulin receptor activator) [34] or glibenclamide (potassium-channel inhibitor) [35] as controls. The results showed that estrone derivative lower glucose levels at doses of $20 \mathrm{mg} / \mathrm{ml}$ than controls and glibenclamide (Figure 2). However, this effect was in a similar form to metformin.

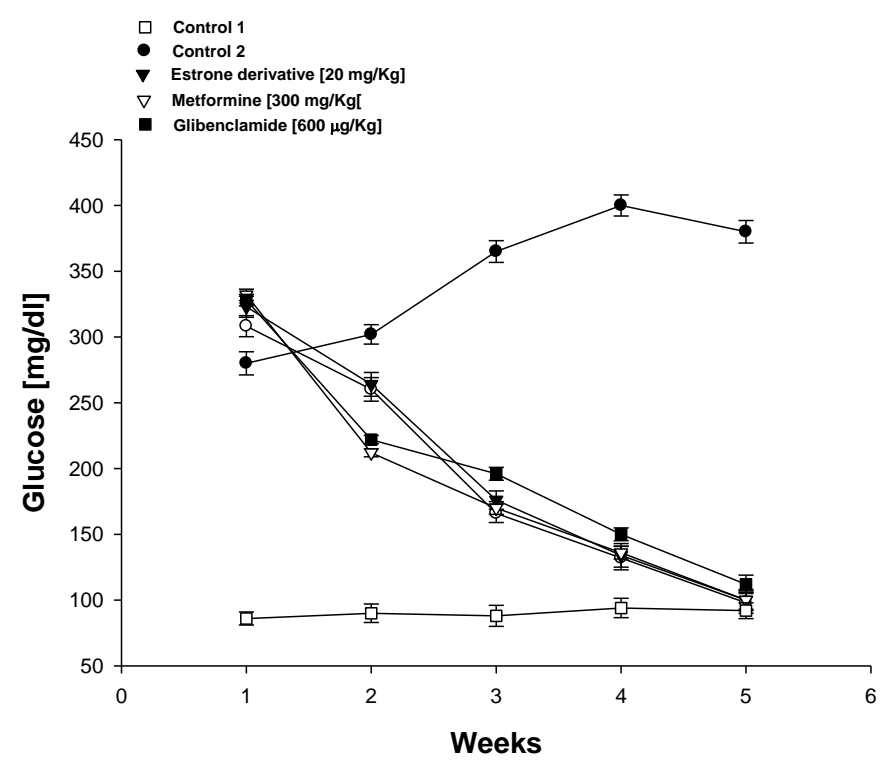

Figure 2. Biological activity exerted by the estrone derivative, metformin, and glibenclamide against glucose levels in a diabetic rat model. The results showed that steroid derivative significantly decreases $(p=0.05)$ in a dose-dependent manner the blood glucose concentration in a similar form to metformin. The effects are expressed as mean \pm S.E. $\mathrm{n}=9$. Control $1=$ Normal rats given $2 \mathrm{ml}$ of normal saline; Control $2=$ Diabetic control rats given $2 \mathrm{ml}$ of normal saline.

On the other hand, it is important to mention that alternative experiments were carried out to find the minimum effective dose by which the estrone derivative could lower the glucose concentration. The results showed that the estrone derivative significantly decreases the glucose concentration in a dose-dependent manner (Figure 3).

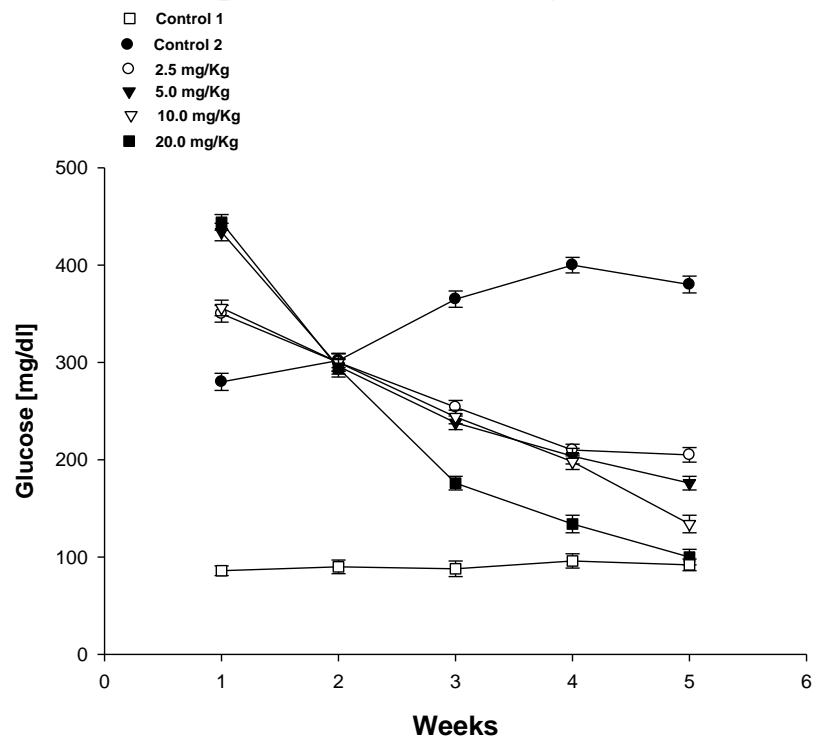

Figure 3. Hypoglycemic activity exerted by the estrone derivative against glucose levels in a diabetic rat model. The results showed that estrone derivatives significantly decreased $(p=0.05)$ in a dose-dependent manner with blood glucose concentration. The effects are expressed as mean \pm S.E. $\mathrm{n}=9$. Control $1=$ Normal rats given $2 \mathrm{ml}$ of normal saline; Control 2 = Diabetic control rats given $2 \mathrm{ml}$ of normal saline. 
These results indicate that the estradiol derivative possibly exerts its hypoglycemic activity through the insulin receptor's activation; to evaluate this hypothesis, a theoretical analysis was performed using docking server software [36].

\subsubsection{Ligand-protein interaction.}

Several methods have been used to predict biomolecules' coupling with some compounds; These techniques involve the flexible coupling of ligands on the surface of either protein or enzyme.

Table 1. Interaction of estrone derivative and glibenclamide with 3iga protein surface.

Glibenclamide

\begin{tabular}{l|l} 
Glibenclamide & Gln6 \\
& Pro7 \\
& Thr 156 \\
& Ala203 \\
& Pro205 \\
\hline Estradiol derivative & Val93 \\
& Tyr95 \\
Ala 110 \\
Thr 113 \\
Glu153 \\
Pro154
\end{tabular}

Table 2. Interaction of estrone derivative and metformin with 3 w12 protein surface.

\begin{tabular}{l|c} 
Metformine & Asp $_{138}$ \\
& Glu $_{141}$ \\
\hline Estradiol derivative & Met $110_{11}$ \\
& Asn $_{111}$ \\
& Asp 138 \\
& Lys $_{197}$ \\
& Ser $_{198}$ \\
& \\
A & B
\end{tabular}
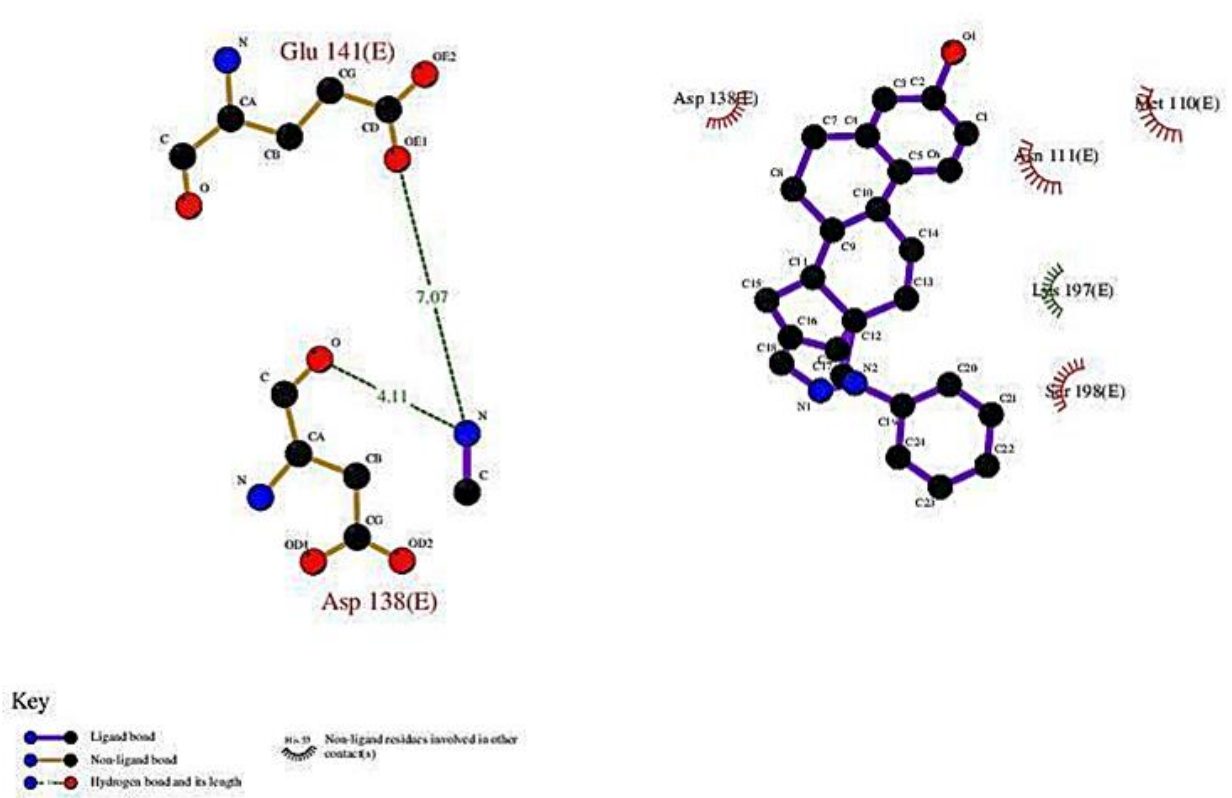

Figure 4. Interaction of either metformin (A) or destrone derivative (B) with 3 w12-protein surface using docking server.

Besides, these studies involve determining the free binding energies and the solvation energies involved between the ligand-biomolecule interaction [37, 38]. Therefore, in this research, a theoretical ass was carried out to evaluate the interaction of estrone derivative 
(compound 4) with either 3iga (potassium-channel inhibitor) [39] or 3w12 (insulin receptor activator) [40] proteins surface. The results (Figures 4 and 5; Tables 1 and 2) showed that there are different amino acid residues involved in the interaction of estrone derivative with either $3 i g a$ or 3 w12 proteins surface. Besides, the inhibition constant (Ki) for estrone derivative was lower compared with either metformin or glibenclamide (Table 3, 4). Furthermore, the estrone derivative showed a higher affinity by $3 \mathrm{w} 12$ protein surface. These data suggest that possibly the Ethynyl-phenylamino-steroid-pyrazole derivative could exert their hypoglycemic activity on glucose levels via insulin receptor activation.

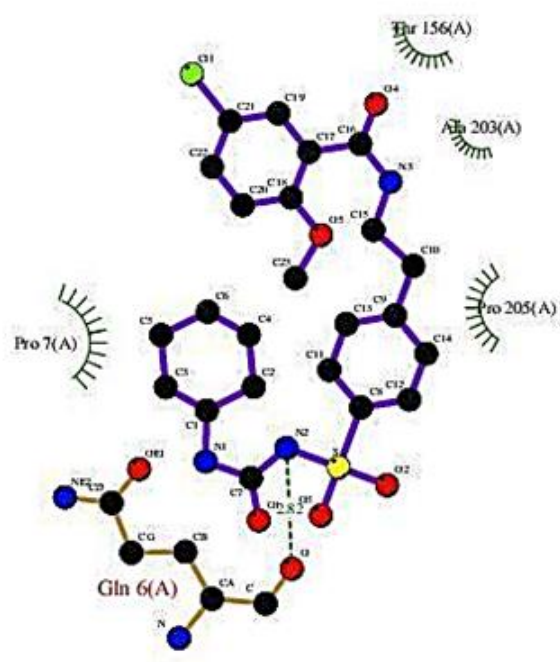

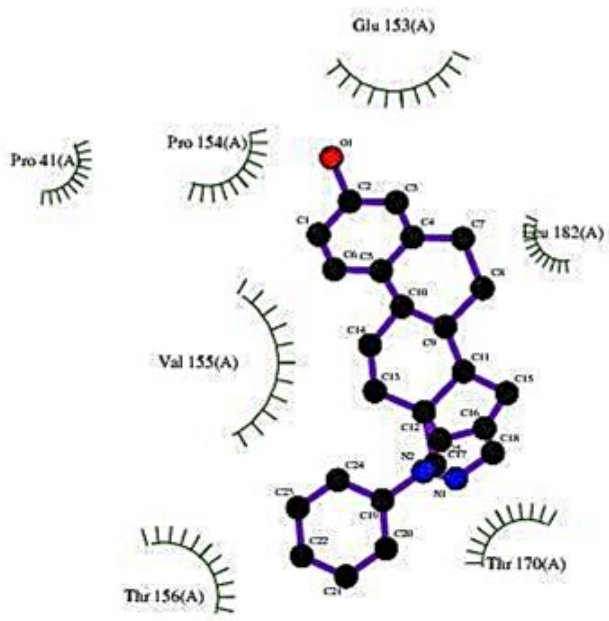

Key

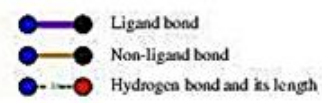

Noa-ligand residues involved in other
contax $(3)$

Figure 5. Interaction of either Glibenclamide (C) or destrone derivative (D) with 3iga-protein surface using docking server.

Table 3. Thermodynamic parameters involved in the interaction of estrone derivative and glibenclamide with

\begin{tabular}{|c|c|c|c|c|c|c|}
\hline \multicolumn{7}{|c|}{ 3iga-protein surface. } \\
\hline Compound & $\begin{array}{lr}\text { Est. } & \text { Free } \\
\text { energy } & \text { of } \\
\text { Binding } & \\
(\text { kcal } / \mathrm{mol}) & \end{array}$ & $\begin{array}{l}\text { Est. } \\
\text { Inhibition } \\
\text { Constant (Ki, } \\
\mu \mathrm{M})\end{array}$ & $\begin{array}{l}\text { vdW + H- } \\
\text { bond + desolv } \\
\text { Energy } \\
(\mathrm{kcal} / \mathrm{mol})\end{array}$ & $\begin{array}{l}\text { Electrostatic } \\
\text { Energy } \\
\text { (kcal/mol) }\end{array}$ & $\begin{array}{l}\text { Total Interm. } \\
\text { Energy } \\
\text { (kcal/mol) }\end{array}$ & $\begin{array}{l}\text { Interact } \\
\text { Surface }\end{array}$ \\
\hline Glibenclamide & -5.57 & 82.29 & -4.88 & -0.14 & -5.01 & 636.44 \\
\hline $\begin{array}{l}\text { Estrone } \\
\text { derivative }\end{array}$ & -6.10 & 34.01 & 6.53 & -0.06 & -6.59 & 643.90 \\
\hline
\end{tabular}

Table 4. Thermodynamic parameters involved in the interaction of estrone derivative and metformin with 3w12-protein surface.

\begin{tabular}{|c|c|c|c|c|c|c|}
\hline Compound & $\begin{array}{lr}\text { Est. } & \text { Free } \\
\text { energy } & \text { of } \\
\text { Binding } & \\
(\mathrm{kcal} / \mathrm{mol}) & \\
\end{array}$ & $\begin{array}{l}\text { Est. } \\
\text { Inhibition } \\
\text { Constant (Ki, } \\
\mu \mathrm{M})\end{array}$ & $\begin{array}{l}\text { vdW + H- } \\
\text { bond + desolv } \\
\text { Energy } \\
(\mathrm{kcal} / \mathrm{mol})\end{array}$ & $\begin{array}{l}\text { Electrostatic } \\
\text { Energy } \\
\text { (kcal/mol) }\end{array}$ & $\begin{array}{l}\text { Total Interm. } \\
\text { Energy } \\
\text { (kcal/mol) }\end{array}$ & $\begin{array}{l}\text { Interact } \\
\text { Surface }\end{array}$ \\
\hline metformine & -4.48 & 518.82 & -2.16 & -2.33 & -4.48 & 246.31 \\
\hline $\begin{array}{l}\text { Estrone } \\
\text { derivative }\end{array}$ & -7.71 & 2.24 & -8.17 & -0.04 & -8.21 & 8.22 .07 \\
\hline
\end{tabular}




\section{Conclusions}

The reagents used in this study for the synthesis of the ethynyl-phenylamino-steroidpyrazole derivative do not require special conditions. Furthermore, the hypoglycemic activity exerted by the ethynyl-phenylamino-steroid-pyrazole derivative against glucose levels is interesting. In this way, this compound could be a good candidate for the treatment of diabetes.

\section{Funding}

This research received no external funding.

\section{Acknowledgments}

To Benjamin Valverde and Raquel Anzurez for unconditional support on this manuscript.

\section{Conflicts of Interest}

The authors declare no conflict of interest.

\section{References}

1. Petrie, M.; Verma, S.; Docherty, K.; Inzucchi, S.; Anand, I.; Belohlavek, J.; Böhm, M.; Chiang, C.; Chopra, V.; de Boer, R. Effect of dapagliflozin on worsening heart failure and cardiovascular death in patients with heart failure with and without diabetes. Journal of the American Medical Association 2020, 323,13531368, https://doi.org/10.1001/jama.2020.1906.

2. Francesco, C.; Peter, J.; Victor, A.; Clifford, J.; Antonio, C. 2019 ESC Guidelines on diabetes, pre-diabetes, and cardiovascular diseases developed in collaboration with the EASD: The Task Force for diabetes, prediabetes, and cardiovascular diseases of the European Society of Cardiology (ESC) and the European Association for the Study of Diabetes (EASD). European Heart Journal 2020, 41, 255-323, https://doi.org/10.1093/eurheartj/ehz486.

3. Chiang, C.; Ueng, K.; Chao, T.; Lin, T.; Wu, Y.; Wang, K.; Sung, S.; Yeh, H.; Li, Y.; Liu, P.; Chang, K.; Shyu, K.; Huang, J.; Tsai, C.; Hung, H.; Liu, M.; Chao, T.; Cheng, S.; Cheng, H.; Chu, P.; Yin, W.; Wu, Y.; Chen, W.; Lai, W.; Lin, S.; Yeh, S.; Hwang, J. 2020 Consensus of Taiwan Society of Cardiology on the pharmacological management of patients with type 2 diabetes and cardiovascular diseases. Journal of the Chinese Medical Association 2020, 83, 587-621, https://doi.org/10.1097/JCMA.0000000000000359.

4. Buse, J.; Wexler, D.; Tsapas, A.; Rossing, P.; Mingrone, G.; Mathieu, C.; Davies, M. 2019 Update to: Management of Hyperglycemia in Type 2 Diabetes, 2018. A Consensus Report by the American Diabetes Association (ADA) and the European Association for the Study of Diabetes (EASD). Diabetes Care. 2020, 43, 487, https://doi.org/10.2337/dci19-0066.

5. Cusi, K.; DeFronzo, R. Metformin: a review of its metabolic effects. Diabetes Reviews 1998, 6, 89-131.

6. Gao, F.; Ma, X.; Peng, J.; Lu, J.; Zhu, W.; Zhou J. The Effect of Acarbose on Glycemic Variability in Patients with Type 2 Diabetes Mellitus Using Premixed Insulin Compared to Metformin (AIM): An Open-Label Randomized Trial. Diabetes Technology y Therapeutics 2020, 22, 256-254, https://doi.org/10.1089/dia.2019.0290.

7. Yen, F.; Yang, Y.; Hwu, C.; Wei, J.; Huang, Y.; Hou, M.; Hsu C. Liver-related long-term outcomes of thiazolidinedione use in persons with type 2 diabetes. Liver International 2020, 40, 1089, https://doi.org/10.1111/liv.14385.

8. Shorr, R.I.; Ray, W.A.; Daugherty, J.R.; Griffin, M.R. Incidence and risk factors for serious hypoglycemia in older persons using insulin or sulfonylureas. Archiv. Int. Med. 1997, 157, 1681.

9. Lai, J.; Wang, M.; Wu, C.; Huang, Y.; Lu, C.; Liou, J. Risk of severe hypoglycemic events from amiodaronesulfonylureas interactions: A population-based nested case-control study. Pharmacoepidemiology y Drug Safety 2020, 28, 842, https://doi.org/10.1002/pds.5034.

10. Dhopeshwarkar, N.; Brensinger, C.; Bilker, W.; Soprano, S.; Flory, J.; Dawwas, G.; Leonard, C. Risk of sudden cardiac arrest and ventricular arrhythmia with sulfonylureas: An experience with conceptual replication in two independent populations. Scientific Reports 2020, 10, 1, https://doi.org/10.1038/s41598020-66668-5.

11. Gan, S.; Barr, J.; Arieff, A.; Pearl, R. Biguanide-associated lactic acidosis: case report and review of the literature. Archives of Internal Medicine, 1992, 152, 2333, https://doi.org/10.1001/archinte.152.11.2333. 
12. Singh, S.; Loke, Y.; Furberg, C. Long-term risk of cardiovascular events with rosiglitazone: a meta-analysis Journal of the American Medical Association 2007, 298, 1189-1195, https://doi.org/10.1001/jama.298.10.1189.

13. Van, M.; Jones, M.; Gunn, D.; Geraci, L.; Jones, J.; Sawicki, D.; Mitschler, A. Discovery of 3-[(4, 5, 7trifluorobenzothiazol-2-yl) methyl] indole-N-acetic acid (lidorestat) and congeners as highly potent and selective inhibitors of aldose reductase for treatment of chronic diabetic complications. Journal of Medicinal Chemistry 2005, 48, 3141, https://doi.org/10.1021/jm0492094.

14. Mariappan, G.; Prabhat, P.; Sutharson, L.; Banerjee, J.; Patangia, U.; Nath, S. Synthesis and antidiabetic evaluation of benzothiazole derivatives. Journal of the Korean Chemical Society 2012, 56, 251-256.

15. Goodwin, N.; Mabon, R.; Harrison, B.; Shadoan, M.; Almstead, Z.; Xie, Y.; Mseeh, F. Novel L-xylose derivatives as selective sodium-dependent glucose cotransporter 2 (SGLT2) inhibitors for the treatment of type 2 diabetes. Journal of medicinal chemistry 2009, 52, 6201, https://doi.org/10.1021/jm900951n.

16. Goodwin, N.; Ding, Z.; Harrison, B.; Strobel, E.; Harris, A.; Smith, M.; Diaz, D. Discovery of LX2761, a sodium-dependent glucose cotransporter 1 (SGLT1) inhibitor restricted to the intestinal lumen, for the treatment of diabetes. Journal of medicinal chemistry 2017, 60, 710, https://doi.org/10.1021/acs.jmedchem.6b01541.

17. Zhang, X.; Jia, Y.; Jackson, E.; Tofovic, S. 2-Methoxyestradiol and 2-ethoxyestradiol retard the progression of renal disease in aged, obese, diabetic ZSF1 rats. Journal of cardiovascular pharmacology 2007, 49, 56, https://doi.org/10.1097/FJC.0b013e31802cb88e.

18. Figueroa-Valverde, L.; Díaz-Cedillo, F.; López-Ramos, M.; Garcia-Cervera, E. Activity induced by two Steroid-Dihydropyrimidine derivatives on Glucose levels in a Diabetic Rat Model. Relationship between descriptors $\log \mathrm{P}$ and $\pi$ and its Antidiabetic activity. International Journal of PharmTech Research 2010, 2075, https://doi.org/10.1097/FJC.0b013e31802cb88e.

19. Volkova, Y.; Antonov, Y.; Komkov, A.; Scherbakov, A.; Shashkov, A.; Menchikov, L.; Zavarzin, I. Access to steroidal pyridazines via modified thiohydrazides. RSC Advances 2016, 6, 42863-42868, https://doi.org/10.1039/C6RA06881B.

20. Shin, S.; Kim, K.; Pak, K.; Nam, H.; Im, H.; Lee, M.; Kim, I. Effects of animal handling on striatal DAT availability in rats. Annals of Nuclear Medicine 2020, 34, 496-501.

21. Figueroa-Valverde, L.; Diaz-Cedillo, F.; Lopez-Ramos, M.; Garcia-Cervera, E.; Pool-Gomez, E.; CardenaArredondo, C. Glibenclamide-pregnenolone derivative has greater hypoglycemic effects and biodistribution than glibenclamide-oh in alloxan-rats. Biomedical Papers 2012, 156, 122-127, http://dx.doi.org/10.5507/bp.2012.028.

22. Figueroa-Valverde, L.; Diaz Cedillo, F.; Rosas-Nexticapa, M.; Mateu-Armand, V.; García-Cervera, E.; Pool Gómez, E.; HauHeredia, L.; Lopez-Ramos, M.; Alfonso-Jimenez, A. Cabrera-Tuz, J. Design and synthesis of two 3-aza-bicyclo[3,3,1]nonane-estrone derivatives. Heterocyclic Letters 2019, 9, 11, https://doi.org/10.22034/AJGC.2018.144189.1093.

23. Hocht, C.; Opezzo, L.; Gorzalczany, S.; Bramuglia, G.; Tiara, C. Una aproximación cinética y dinámica de metildopa en ratas con coartación aórtica mediante microdiálisis. Revista Argentina de Cardiología 1999, 67, 769. 24.

24. Liu, H.; Lieberzeit, Z.; Anthonsen, T. Synthesis and Fungicidal Activity of 2-Imino-3-(4-arylthiazol-2-yl)thiazolidin-4-ones and Their 5-Arylidene Derivatives. Molecules 2000, 5, 1055-1061, https://doi.org/10.3390/50901055.

25. Lauro, F.; Francisco, D.; Marcela, Elodia, G.; Eduardo, P. ; Marissa, C. Design and synthesis of some carbamazepine derivatives using several strategies. Letters in Organic Chemistry 2015, 12, 394-401, https://doi.org/10.2174/1570178612666150331205124.

26. Li, D.; Mao, X.; Chen, H.; Chen, G.; Liu, P. Rhodium-catalyzed addition-cyclization of hydrazines with alkynes: pyrazole synthesis via unexpected C-N bond cleavage. Organic letters, 2014, 16, 3476-3479, https://doi.org/10.1021/ol501402p.

27. Deng, X.; Mani, N. Reaction of N-monosubstituted hydrazones with nitroolefins: A novel regioselective pyrazole synthesis. Organic Letters 2006, 8, 3505-3508, https://doi.org/10.1021/o1061226v.

28. Armstrong, A.; Jones, L.; Knight, J.; Kelsey, R. Oxaziridine-mediated amination of primary amines: Scope and application to a one-pot pyrazole synthesis. Organic letters 2005, 7, 713-716, https://doi.org/10.1021/o10474507.

29. Molteni, G. Silver (I) salts as useful reagents in pyrazole synthesis. Arkivoc 2007, 2, 224-246.

30. Chen, B.; Zhu, C.; Tang, Y.; Ma, S. Copper-mediated pyrazole synthesis from 2, 3-allenoates or 2-alkynoates, amines and nitriles. Chemical Communications 2014, 50, 7677-7679, https://doi.org/10.1039/C4CC02856B.

31. Lauro, F.; Francisco, D.; Elodia, G.; Eduardo, P.; Maria, L.; Marcela, R.; Landy, C. Evaluation of activity inotropic of a new steroid derivative using an isolated rat heart model. International Journal of Clinical and Experimental Medicine 2014, 7, 1223.

32. Figueroa-Valverde, L.; Diaz-Cedillo, F.; López-Ramos, M.; García-Cervera, E.; Pool-Hernandez, E. Synthesis and design of a progesterone-alkyne derivative. Bulgarian Chemical Communications 2012, 44, 139-143. 
33. Lenzen, S. The mechanisms of alloxan-and streptozotocin-induced diabetes. Diabetologia, 2008, 51, 216226.

34. Bouras, H.; Roig, S.; Kurstjens, S.; Tack, C.; Kebieche, M.; De-Baaij, J.; Hoenderop, J. Metformin regulates TRPM6, a potential explanation for magnesium imbalance in type 2 diabetes patients. Canadian journal of physiology and pharmacology, 2020, 98, 400-411, https://doi.org/10.1139/cjpp-2019-0570.

35. McClenaghan, C.; Huang, Y.; Yan, Z.; Harter, T.; Halabi, C.; Chalk, R.; Nichols, C. Glibenclamide reverses cardiovascular abnormalities of Cantu syndrome driven by K ATP channel overactivity. The Journal of Clinical Investigation 2020, 130, 1116-1121.

36. Lung, J.; Lin, Y.; Yang, Y.; Chou, Y.; Shu, L.; Cheng, Y.; Wu, C. The potential chemical structure of antiSARS-CoV-2 RNA-dependent RNA polymerase. Journal of Medical Virology, 2020, 92, 693-697, https://doi.org/10.1002/jmv.25761.

37. Weng, G.; Wang, E.; Wang, Z.; Liu, H.; Zhu, F.; Li, D.; Hou, T. HawkDock: a web server to predict and analyze the protein-protein complex based on computational docking and MM/GBSA. Nucleic Acids Research 2019, 47, W322-W330, https://doi.org/10.1093/nar/gkz397.

38. Idris, M.; Yekeen, A.; Alakanse, O.; Durojaye, O. Computer-aided screening for potential TMPRSS2 inhibitors: a combination of pharmacophore modeling, molecular docking and molecular dynamics simulation approaches. Journal of Biomolecular Structure and Dynamics, 2020, 1-19, https://doi.org/10.1080/07391102.2020.1792346.

39. Thompson, A.; Kim, I.; Panosian, T.; Iverson, T.; Allen, T.; Nimigean, C. Mechanism of potassium-channel selectivity revealed by $\mathrm{Na}+$ and $\mathrm{Li}+$ binding sites within the KcsA pore. Nature Structural and Molecular Biology 2009, 16, 1317.

40. Menting, J.; Whittaker, J.; Margetts, M.; Whittaker, L.; Kong, G.; Smith, B.; Lawrence, M. How insulin engages its primary binding site on the insulin receptor. Nature 2013, 493, 241-245. 